Bruce Cronin, The rise and decline of the Business Roundtable? Published in Think tanks and global politics: Key spaces in the structure of power, edited by Alejandra Salas-Porras and Georgina Murray, 2017, Palgrave Macmillan, reproduced with permission of Palgrave Macmillan. Embargoed to March 2020.

\title{
The Rise and Decline of the Business Roundtable?
}

\author{
Bruce Cronin ${ }^{1}$ \\ University of Greenwich \\ b.cronin@greenwich.ac.uk
}

\section{Introduction}

As the organised voice of the largest corporations in the world's largest economy, the US Business Roundtable has gained notoriety not only for its potential power but also its effectiveness, spurring imitators from Canada to Australia and New Zealand. Since its formation in the early 1970s the Roundtable has won remarkable legislative victories and built popular support for the notion of what is good for business is good for America. Yet at the same time, it has also been adept at compromise and retreat, which has led some to suggest its time has passed. With echoes of the passing of the Roman Empire, John Jurris (2000) and more recently Mark Mizruchi (2013) have suggested that the very success of the Roundtable in winning early victories over labour rights and the reach government regulation removed its raison d'etre, winning the battle but losing the war of reshaping the US polity.

\footnotetext{
${ }^{1}$ I am grateful to Bill Carroll and David Peetz for their detailed and constructive comments on this paper, to David Dekker for the lobbying competitiveness metaphor and Larry Su for suggesting the divergence test employed.
} 
While arguably representing the narrow interests of a particular group of firms, the Business Roundtable meets the criteria for 'Think Tanks' presented by Georgina Murray in chapter three of this volume: 'permanent persuaders’ providing allegedly non-partisan expert opinion on policy matters in an attempt to influence these. While it directly represents the interests of large industrial companies as members, since these firms comprise a central part of economic activity the Roundtable's positions have a potentially very wide impact on society. Certainly, it has aimed and succeeded in reframing the political agenda on major economic issues.

Burris (1992) categorises the Roundtable as a 'moderate-conservative' lobbying group distinct from the ‘ultra-conservative’ National Association of Manufacturers (NAM) and Chamber of Commerce lobbying groups and from 'moderate-conservative' research groups such as the Committee for Economic Development (CED). Where research groups tend to develop and apply ideological positions to policy matters, the Roundtable has been quite pragmatic from the start, pursuing the interests of business in general and big business where there is a conflict, but avoiding narrow self-interests of particular members. It is distinguished from other interest groups in framing this pragmatism within popular tropes and mobilising grass-roots support.

This direct, pragmatic yet long-run engagement by the CEOs of the largest US industrial companies in policy matters meets Gramsci's definition of 'organic intellectuals', engaging not only economically but also in social and political arenas:

The capitalist entrepreneur ... already characterised by a certain directive and technical (i.e. intellectual capacity) ... must be an organiser of masses of men ... an organiser of the “confidence” of investors ... If not all entrepreneurs, at least an élite among them must have the capacity to be an organiser of society in general, including all its complex organism of services, right up to the state organism, because of the need to create the conditions most favourable to the expansion of their own class ... (Gramsci 1971, pp. 5-6). 
In this chapter I review the rise of the Business Roundtable, examine the organisational methods underpinning its success and consider whether it is now in a state of decline. I predominantly employ an historical method, drawing on a variety of accounts of the major policy battlegrounds over the last fifty years in some detail. I supplement this with a social network analysis of the changing position of the Roundtable in the network of Congressional lobbying, utilising a little-used dataset (see Lee and Cronin 2016 on the value of combining such methods in heterodox research).

\section{Origins}

As meticulously detailed by Linder (2000), the immediate origins of the Business Roundtable lie in the corporate mobilization from the late 1960s against the perceived power of unions in general and construction unions in particular. But as Domhoff (1983) points out, the organisations that coalesced at this time had long roots in the Business Council, the centre of business policy networks since 1933. He quotes DuPont chair Irving Shapiro: 'The Roundtable was created to have an advocacy organization. It wasn’t created by the Business Council, but by the same people.' (Domhoff 1983, p. 135).

Union power in the construction sector was particularly problematic for industrial firms in the 1960s. While many large US manufacturers had responded to rising labour costs by relocating production offshore in the 1960s and 70s, construction unions were largely impervious to this as their production was inherently localised. Rising construction costs from labour shortages arising from the Vietnam draft directly impacted on large US industrial firms when constructing new plant (Linder, 2000).

Amidst a variety of industry responses to the escalation in construction costs, a key figure was US Steel Corporation CEO Roger Blough, who, in a bid to weaken union power, halted construction work on his plants in June 1967 to deny alternative employment to workers striking against local contractors. US Steel was joined by large local employers Westinghouse and Jones and Laughlin. Chamber president and construction firm owner Winston Blount subsequently called for more widespread united employer action against construction unions (Linder, 2000). 
In May 1969, a Construction Users Anti-Inflation Round Table (CUAIR) was established to build solidarity among large industrial firms in setting common terms when agreeing construction contracts and to find methods to reduce the power of construction to press wage increases. A distinct feature of the group, which would also come to characterize the Business Roundtable, was that it solely comprised CEOs or chairs of major industrial companies. Roger Blough agreed to chair the CUAIR on the condition that member CEOs agreed to personally participate in the policy committee (Linder, 2000). Founding participants comprised CEOs or chairs from GE, Standard Oil of New Jersey, Union Carbide, Kennecott Copper, GM, and AT\&T. Other early participants included Alcoa, Shell, Bechtel, Ebsasco, Procter \& Gamble, Dow Chemical, B.F. Goodrich, International Paper, Consumers Power, Aluminum Company of America, American Electric Power, General Dynamics, Humble Oil, Owens-Corning, Texaco and DuPont.

By 1972 Blough had turned to broader concerns, working with Alcoa CEO John Harper to bring together a number of groupings of senior executives agitated by prevailing labour conditions, largely to rationalise existing overlapping membership. The CUAIR became the Construction Committee and a 'Labor Law Study Group’ became the Labor Law Committee of the new Business Roundtable - For Responsible Labor-Management Relations in October 1972, each with a full-time executive director. The 'March Group’ an informal network of CEOs which had for a long time met at the New York members' Links Club merged in early 1973 (Linder, 2000; Waterhouse, 2014).

\section{Modus Operandi}

A key organising principle of the Business Roundtable is the direct engagement of the CEOs of the largest US industrial corporations in its daily activity. Blough's experience in the sluggish politics of business representative organizations and his direct involvement in US Steel's conflict with construction unions proved the need to unite these key decision makers in what many business figures interpreted as an existentially defining period. The mobilization of CEOs, in turn, generates direct access to very senior levels of government; the Roundtable’s first lobbying activity on formation was a meeting of half of its 
executive with the White House Budget Director, the Federal Reserve chair and the chair of the Council of Economic Advisors (Waterhouse, 2014).

A second characteristic of the Roundtable is its industrial composition. Members are overwhelmingly vertically integrated industrial firms operating in stable regulated markets with few competitors. While the particular industries represented shifted with changes in economic structure, pharmaceuticals, telecoms and IT in place of engineering, until the late 1990s it remained apart from the finance sector banks, insurance firms - and from investment capitalists throughout, who were caste as a destabilising influence on business (Waterhouse, 2014).

Third, the Roundtable eschews partisan politics in preference for a long-term effort to build support across Congress and did not fund PACs or individual candidates, though individual corporates do; John Harper (Alcoa) and Irving Shapiro (DuPont) were prominent Democrats, Blough and John Young (Hewlett Packard), Republicans (Waterhouse, 2014). Instead, the Roundtable organizes around a set of task forces focused on legislative areas deemed to be restricting business; in addition to the labour law and construction committees, there were initially task forces on consumerism, taxes, environment and trade; these expanded to other topics as the need arose. Each task force was chaired by a CEO with administrative support from the CEO’s firm; the Roundtable itself had few administrative staff (9 in 1974; 11 in 2004), though the expenditure on hired attorneys and lobbyists remained substantial. This was funded by membership fees of $\$ 2,500$ to $\$ 35,000$ per annum, a total of $\$ 1.9$ million in 1974, 161 members paying $\$ 10,000$ to $\$ 35,000$ and a total of $\$ 3$ million by 2004 (Slavin 1975; Domhoff 2006). Recent spending on lobbying is reported in Figure 6.1.

\section{ENTER FIGURE 6.1 AROUND HERE}

Fourth, the Roundtable effectively combines national coalitions of business organisations with grass roots mobilisations of their members and their allies and employees at local levels. The Roundtable Construction Committee initially continued CUAIC efforts to mobilise local ‘user groups' in solidarity 
against local construction unions and in Congressional lobbying. This was extended to employees and household consumers in a major employer organisations’ mobilization against the 1977 Labor Law Reform Bill which saw an unprecedented wide coalition and the first business use of grassroots lobbying. Thereafter, the focus of popular mobilisation was to support specific legislative efforts (Waterhouse, 2014).

The Roundtable's focus, then, is more tactical than the propagation of abstract principles characteristic of research-oriented Think Tanks. An early foray into this area, an expensive, public relations campaign in the Readers Digest to improving public perceptions of business was quickly dropped when measurable impact on public opinion was detected (Waterhouse 2014). The Roundtable maintains a pragmatic legislative focus, drawing on the well-honed tactical skills of business competition, deployed and developed skills in exploiting the political divisions of the day and framing their goals within universal popular concerns ahead of narrow business interests.

\section{Effectiveness}

To assess the effectiveness of the Roundtable's lobbying activity, a set of major issue areas that the Roundtable has engaged in are considered. These cover labour, inflation, consumer protection, regulation, taxation, trade and healthcare.

\subsection{Labour}

By Linder's (2000) account, the Roundtable precursor, the CUAIR had sought to create a 'united front' among employers to expand supply of skilled labour, avoid overtime, stop local building during local strikes and to support local collective bargaining. The organisation gained regular access to senior members of the administration but was not effective in effecting government intervention in collective bargaining. The CUAIR funded research on non-union contracting and provided and funded legal representation for small contractors in labour disputes, rolling back union picketing rights, and formed dozens of construction local user groups to build employer solidarity. 
A key target for employers became union hiring halls. Contractors depended on hiring halls in order to maintain a steady supply of specialist combinations of labour. These were readily unionised, providing an organisational focal point with highly skilled and unionised crafts at their core. Attempts to limit union power here typically faltered against individual contractors' needs for labour and the alternative costs of the complex personnel administration in-house. In January 1971 Blough called for a 'hard crackdown on construction unions' and advocated use of non-union contractors; a non-union hiring hall was established in Houston later in the year.

The position of unionised contractors declined through the 1970s, their share of domestic contracts falling from 69 to 41 percent 1965-75, with non-unionised contractors gaining market geographic share. The non-unionised Associated Builders and Contractors (ABC) doubled its membership to 10,000 1972-76, accounting for 32 percent of non-residential construction by 1971, and gaining large-scale industrial projects from Roundtable firms. In 1970 DuPont, which had previously used unionised contractors, awarded three contracts to non-unionised construction firms, in pursuit of lower construction costs. By 1974 half of DuPont's construction was undertaken by non-unionised firms. In 1973 Shell Oil awarded a \$12 million contract for a natural gas plant to a non-unionised Houston firm, the first non-union contract in highly-unionised Michigan.

At the same time, uneven supply of skilled workers in complex projects at critical locations and times, sustained unionised contractors. Attempts to regularise the supply of skilled labour saw the Nixon administration, with support from unionised contractors, introduce training programmes and tripartite bargaining in the construction industry to limit local wildcat strikes. The Business Roundtable, now on the scene, called for legislation to give national unions control over their local branches but saw the main mechanism being increased employer bargaining power through strengthened local contractors associations.

In April 1975, the Ford administration attempted to legislate for larger area bargaining, accompanied by a concession to allow secondary picketing of non-union subcontractors. The Roundtable immediately 
resolved to oppose this, noting the major cost reductions coming from the growing non-union sector. They reiterated their preference for local employer solidarity over larger area bargaining that would strengthen national unions and spill-over into other industries. Employers mobilized against the extension of picketing via a National Right to Work Committee campaign, vigorously supported by Ronald Reagan, who was contesting Ford for the Republican presidential candidacy, leading Ford to veto the Bill after Congress passed it. When the bill was reintroduced to Congress by the Carter administration in 1977, it was decisively defeated, amidst vigorous opposition from the Roundtable and a wide coalition of business organisations. By 1984 the Roundtable could report an overall decrease in construction wages by 45 cents per hour.

In summary, Linder (2000, p. 414) argues that 'the Roundtable was unable to secure enactment of its national legislative agenda, but it did thwart the AFL-CIO’s congressional initiatives. Its most important accomplishment, undermining unions' quasi-monopoly of the large-scale industrial construction so vital to Roundtable members’ accumulation strategies, was a self-help measure undertaken largely without state assistance.’

\subsection{Inflation}

By Waterhouse’s (2014) account, in a position of relative weakness in the early 1970s, generated by labour shortages and spiralling prices driven by the Vietnam War, business had pragmatically called for government controls on wages and had supported Nixon's New Economic Policy from August 1971-73, introducing wage and price stabilization. The programme was supported by 70 per cent of public polled and publically welcomed by, amongst others, the chairs of GM, Chrysler, Metropolitan Life Assurance, Republic Steel, Pan American Airlines. While contested among their membership and qualified as 'a necessary evil' the NAM and Chamber also supported the programme. But as controls could only effectively be short-lived, employers were concerned to strengthen their bargaining position once controls were lifted. Accordingly, the Chamber mounted a public relations campaign associating labour power and government spending as underpinning causes of price inflation. 
By contrast, the Roundtable agitated from the start against further government controls on business. The CUAIC's first act following its October 1971 formation was a meeting with senior government officials where they made a vigorous call for the immediate cessation of the controls. In Congressional hearings on possible extension of controls in 1974, the Roundtable and individual members argued that controls were associated with economic decline as they restricted investment.

The linkage between government spending, union power and inflation, worsened by government was deployed tactically in a major mobilization against proposed extended picketing rights in the 1977 Labour Law Reform Bill discussed above. The Roundtable, NAM and Chamber sought common cause among big and small employers and consumers, who it was alleged would suffer from enhanced union power. Similarly, the three lobbied successfully against the 1978 Equal Opportunity and Full Employment Bill, on the grounds that full employment at prevailing union rates would fuel inflation.

The Roundtable and NAM initially tolerated Carter’s 1978 voluntary wage and price restraint as the price of reduced government spending. But as the administration applied more complex wage and price guidelines in the face of the 1979 oil price shock, the Roundtable, NAM and National Association of Retailers turned against wage and price guidelines in favour of the 'hard policy choices' being prompted by the accession of Paul Volcker as chairperson to the Federal Reserve and his aggressive 1979-82 monetary restrictions and the accompanying recession.

\subsection{Consumer protection}

With rising affluence through the 1960s, greater exposure of product failures and sympathetic Democrat administrations public support grew for consumer rights beyond caveat emptor, crystallised on 1969 calls for a Consumer Protection Agency (CPA). Business organisations mobilized against the perceived state encroachment on their decision-making, the Roundtable establishing a Consumer Issues Working Group (CWIG) in 1973. Acknowledging widespread popular support for consumer rights legislation, the CWIG did not oppose this directly but sought to rally the minority opposition in Congress to delay and amend to 
limit the effectiveness of proposals. A grass-roots strategy was deployed to lobby the minority congress members, asking small business members of the NAM to write to Congress as independent voices.

Alongside the congressional initiative, the Roundtable led efforts to try to shape public opinion on the issue, commissioning a public opinion poll that counterpoised creation of a new, overarching and expensive Federal agency against improving the effectiveness of effective agencies. With 75 percent of respondents supporting the loaded answer, the poll result was promoted widely and effectively against the CPA proposal, while reinforcing the general business position against state encroachment and exploiting public distrust of state bureaucracy and paternalisation. When the Bill passed Congress in 1975, Ford, under pressure from business-aligned Reagan for the Republican nomination, succumbed to the business lobby to veto it. On resubmission under Carter in 1978, sustained business public relations campaigning against big government dissuaded congressional support (Waterhouse, 2014).

\subsection{Regulation}

By the late 1970s, the Roundtable had succeeded in weakening union and consumer protection rights, defeating price controls and committing successive administrations to reducing government spending. They had done this with considerable tactical nous in building wide coalitions exploiting the political divisions of the day in Congress but framing each targeted issue as part of a burden on business efficiency that was economically detrimental to the public as consumers. On this basis they turned their attention towards a more comprehensive reduction in government regulation of business.

A precursor to the push for regulatory reform was the industrial deregulation of the Carter administration. Regulation of airlines, trucking and telecommunications had been established in the Progressive and New Deal eras to protect firms from excessive competition (Coase 1959; Kolko 1963). But by the 1970s a sufficiently complex set of imperfections, market and price restrictions, capacity and expansion limitations had developed that the incumbent firms welcomed change, though were highly divided in their response to specific proposals. Consequently, the national business organisations, including the Roundtable, who typically represented both winners and losers from specific deregulation proposals had 
discussed the need for regulatory reform for many years without consensus and thus were not highly motivated to mobilise to resist change (Derthick \& Quirk 1985).

While quiet on deregulation, the Roundtable was a vocal opponent of any new regulation without strong cause. As part of his anti-inflation policy, Ford accepted the view that government regulation often generated hidden costs and mandated a cost-benefit analysis for all new government regulations. The Roundtable quickly established a regulation task force under Irving Shapiro (DuPont) to collect a mass of examples of 'harmful or unnecessary' regulations from members and estimates of their cost. They then used these examples to lobby for legislation for comprehensive regulatory reform (Waterhouse 2014).

However, Waterhouse (2014) argues the Roundtable made two tactical mistakes in promoting the legislation. First it pressed for a clause removing the presumption that a proposed regulation was valid unless proved otherwise. Second, it opposed a proposal requiring regulatory agencies to provide small firms with regulatory exemptions and flexibility in application. These proposals weakened unity within the coalition of large and small businesses and strengthened the resolve of their opponents, leading Carter to drop comprehensive reform in favour of a small business-focused Regulatory Flexibility Act, without mandated cost-benefit analysis.

Reagan's 1981 election provided a fillip to the pursuit of regulatory reform, with a new executive order requiring cost-benefit analysis of existing regulations where compliance costs exceeded $\$ 100$ million and the creation of a Presidential Task Force on Regulatory Relief. The task force asked the Roundtable to identify the ten regulations that could be changed to greatest benefit and then opened itself up to take complaints of regulatory burden from businesses. Efforts to resubmit comprehensive regulatory reform through the Democratic-controlled House were unsuccessful, but presidential regulatory review under Reagan saw regulatory capacity diminished by the widespread appointment of anti-regulation advocates to head regulatory agencies (Waterhouse 2014). 


\subsection{Fiscal policy}

By Waterhouse's (2014) account, the government deficit was seen by the Roundtable not only as a driver of inflation (deficit spending detached from productivity growth) but also as crowding out funds for business investment. Because the government was borrowing to finance the deficit, firms had to pay higher rates to borrow capital for investment. Thus the government deficit undermined the ability of firms to invest to modernize plant, increase productivity and develop their competitiveness against growing foreign exports. Further, as Roundtable taxation task force chair and GE CEO, Reginald Jones argued in 1975, not only did government fiscal policy make it expensive to raise capital externally, tax policies made it difficult to fund investment from retained earnings.

The Roundtable pursued an acceleration of the depreciation rate allowed as a tax deduction. Since 1934 firms had been allowed to deduct the cost of wear and tear on plant and equipment from the amount liable to pay tax on. Governments had periodically shortened or increased the period of wear and tear deemed needed before replacement in order to encourage or discourage capital investment. The Roundtable argued that the economic difficulties of the 1970s demanded increased capital investment and advocated a reduction in the capital replacement period (depreciation rate). The proposal was supported by a lobbying mobilization by the Roundtable, NAM, Chamber, and a range of trade associations, reframing the desire for tax relief as a contribution to national competitiveness and economic growth.

But while reduced capital depreciation periods were valuable to the large capital-intensive industrial firms at the heart of the Roundtable, smaller firms with lower capital expenditure were more interested in lower interest rates and reductions to the gross rate of corporation tax. Tax reduction campaigns had spread since the success of a 1978 referendum on the issue in California. This 'supply side' movement advocated a general reduction in taxation, and business taxation in particular, to provide more incentives for entrepreneurial activity and competition as a driver of productivity.

Reagan's election embraced the latter generalized tax cut policy, which he incorporated alongside \$140 billion government spending cuts in the 1981 Economic Recovery Tax Bill. This, together with 
reductions in regulation and stable monetary policy, were sufficient to bring a broad sway of business leaders, including the Roundtable to support the new policy regime. When reduced depreciation rates were included, the Roundtable assembled the usual coalition and grassroots mobilization to support the Bill, overwhelming the Democrat-controlled house.

But the Act did not survive the severe recession the Reagan administration immediately faced, providing little scope for the proposed spending cuts yet the tax cuts opening up the deficit and increasing pressure on interest rates. In a bid to reduce the deficit and increase the availability of capital for investment, in mid-1982 the Roundtable called for a closing of the deficit by a reversal of the tax cuts, albeit retaining the lower headline marginal rates. But this broke the coalition with the Chamber and other trade associations of smaller firms who valued the tax cuts much more and divided the Roundtable itself, with less capital-intensive firms less committed to the deficit reduction goal (Ehrbar 1982). Taxes were subsequently substantially increased by the administration in the Deficit Reduction Act of 1984 but this was mainly through reductions in corporate allowances, including a third of the depreciation allowance (Martin 1991; Waterhouse 2014).

In 1983, amidst recession and a renewed rising government deficit the Roundtable established a budget task force chaired by Cigna Insurance CEO Robert Kilpatrick who launched a campaign to restrain government spending. In 1985 the Roundtable organized a nationwide letter-writing campaign among their employees, mobilizing a million around a call to 'Halt the Deficit', involving cuts to defence and social security. But unusually untuned to public sentiment and the fine lines of political divisions, and with divisions on the issue within the Roundtable and among other business associations, the campaign failed to win over the House Democrats. Instead, with Democrat support, the administration reduced the corporate tax rate from 46 percent to 34 percent but removed \$100 billion annual tax exemptions.

Only Bush’s 1990 deal with the Democrats to combine spending cuts with increases in marginal tax rates made inroads into the budget deficit, a deal advocated by the Roundtable and NAM with wide support from major CEOs over Chamber and NFIB opposition (Mizruchi 2013; Waterhouse 2014). Having lost 
tax cuts under Bush I and maintained by the Clinton administration, the Republicans were insistent on reversing these under Bush II, who would not entertain cuts to business taxation until personal tax cuts were enacted. The Roundtable and NAM agreed to this and were subsequently rewarded with cuts to capital gains and dividends and accelerated depreciation allowances (Mizruchi 2013), their priorities for economic growth tied to the 2002-03 WTO negotiations.

\subsection{Trade}

The Roundtable had opposed NAM and Chamber proposals in the early 1980s for an industrial revitalization programme as overly statist and misrepresenting the state of US competitiveness. Instead, the Roundtable, via its trade taskforce under Lee Morgan (Caterpillar), advocated free-trade agreements to allow US firms to compete on a larger international scale. The Roundtable joined with the Round Table of European Industrialists in 1987 to advocate a WTO in place of the GATT, and with the Canadian Business Council on National Issues for a US-Canadian free trade agreement. Roundtable member Edson Spencer (Honeywell) argued that an expansion of international trade and investment would stimulate US industry. Prominent Roundtable firms led the US-NAFTA coalition, undertaking state-level public relations campaigns, eventually winning the Clinton Democrats to the policy, albeit with qualified side agreements on labour and environmental standards.

In accounts of the Roundtable’s legislative programme, little attention has been given to the organisation's efforts to secure liberalisation of international trade and investment, perhaps taking this for granted and seeing little conflict at stake. But as Milner (1988) has emphasised, the shift towards free trade was initially bitterly opposed by less competitive industrial sectors. For the most competitive industrial sectors, that the Roundtable tended to represent, liberalisation of international trade and investment was a major prize. 


\subsection{Health care reform}

By Judis' (1995) account, in the face of rapidly rising health insurance costs, the Business Roundtable advocated systematic reform against Reagan proposals to deregulate healthcare. The Roundtable, via Xerox and the big steel firms, engaged with the 1986 National Leadership Commission on Health, which recommended universal reform. In 1991 this group of big employers proposed that businesses that did not pay insurance be taxed to cover the uninsured, thus reducing the overall cost, a proposal endorsed by the Chamber in 1993.

When the Clinton administration moved to enact this proposal the Roundtable, National Association of Manufacturers and the Chamber initially supported it. But a coalition of small business organisations, health insurers, drug companies and conservative media mobilized to turn public opinion and the peak organisations against any mandatory health insurance. This would allow small businesses to continue to avoid contributions to insurance premiums or taxes and prevent the capping or regulation of premiums paid to insurance firms or prices paid for drugs or healthcare.

Noting that public support for the detail of the Health reform rested on trusting the President, Conservative media, centred on The American Spectator, mounted an unrelenting campaign to undermine the credibility of Clinton's past personal and business dealings. In six months, public support for the plan fell from 59 to 46 percent. Amidst this growing public uncertainty, the Chamber came under pressure from large members that did not provide insurance, including Pepsico, General Mills and Woolworths. Meanwhile the National American Wholesale Grocers' Association resigned from the coalition and many small members defected to the National Federation of Independent Business that was campaigning against reform. Within the Business Roundtable, opposition was mobilised within its Health, Welfare and Retirement Task Force, chaired by the CEO of Prudential Insurance, and including eighteen firms either in health or did not insure their workers. This group eventually convinced the Roundtable to oppose the plan and the NAM and the Chamber then followed. 
Through the Bush II administration, the Roundtable continued to press for reduced health insurance costs, the major cost item for large employers. Immediately after Obama’s election in 2008, the Roundtable, the NFIB, America's Health Insurance Plan (AHIP), and the American Association of Retired Persons advocated universal insurance to spread the costs of health care. The Roundtable eventually supported Obama's capping costs of treatment, despite reservations that they would have to fund the shortfall for their employees. The AHIP, Chamber and NFIB opposed yet were defeated (Mizruchi 2013).

Judis (1995, p. 13) sees health care reform as an example of 'American business [lacking] the kind of farseeing leaders who have the intelligence, objectivity, and authority to unite it around its long-term interests.' But it can also be interpreted as tactical manoeuvring to reconcile a range of diverse business interests, and a pragmatic response to the outcome.

\subsection{Evaluation}

The case studies suggest that the Roundtable's modus operandi repeatedly secured legislative success. In each case a specialised task force was established to develop detailed proposals attuned to the political landscape of the day. This then brokered coalitions with a wide range of other business organisations, with differing interests and policy objectives, to unite on the specific proposal. Congress and the administration were systematically lobbied from a wide range of organisations, reinforced by grassroots mobilisation of individual members and their employees to build up a groundswell of public opinion in support of the proposal. In these mobilisations the proposals were carefully framed within a popular trope, such as opposition to rising prices, taxation or big government.

Table 6.1 summarises the outcomes of the cases discussed. The historical evidence suggests that in all but two of the policy areas the Roundtable achieved its goals of preventing further encroachments of state regulation and in reframing the policy debate. In the case of fiscal policy, it initially won tax and deficit reductions but saw these later reversed. In the case of health care reform, it stalled the changes it opposed and eventually found a compromise. But the great gains in rolling back labour rights and inflation in the 
1970-80s and international trade and investment in the 1980s-90s, undoubtedly outweighed the qualified outcomes elsewhere, for these were viewed as existential issues for business.

\section{ENTER TABLE 6.1 AROUND HERE}

\section{Decline?}

The early rapid gains of the Roundtable against organised labour in the 1970s are often counterpoised to the more mixed results of the 1980s and the complex and at times paralysed policy environment that followed. If the Roundtable's early success is attributable to its composition as the powerful commanding heights of the economy, why has this power not created continued and unchecked dominance of the policy agenda since?

Two arguments are commonly advanced to explain this paradox, fragmentation and it's being the victim of its success. The fragmentation thesis is that structural changes in the economy associated with globalisation and technical change have undermined the industries in which the Roundtable has been rooted and thus its economic power and political influence; it has struggled to respond to the changing environment. The victims of success thesis is that the sophisticated tactics and overwhelming resources invested in lobbying that enabled the early policy gains have overwhelmed the political system, paralysing effective decision making and consensus formation, leading to outcomes against the interests of the dominant participants.

These arguments will be evaluated in their own terms and in the light of the case studies presented then considered in the light of an empirical analysis of the Roundtable's position in the structure of lobbying activity over time.

\subsection{The fragmentation thesis}

Waterhouse (2014) points to a generational shift in the Roundtable in the early 1980s as foundational 'charismatic' leaders retired and a weakening of the industrial sector in the structure of the US economy and thus a decline in its influence. Mizruchi (2013) argues that this reflected increased expectations of 
shareholder value maximisation among Fortune 500 firms, whose average CEO tenure fell from 9.7 years in 1982 to 6.8 years 2002. The weakening social cohesion amongst the economic elite from increased turnover was reinforced by a decline in director interlocking among firms, as board membership diversified with internationalisation and director workload increased with new obligations under the Sarbanes Oxley Act. Average interlocks among SP1500 firms falling from 7.14 to 4.98 2000-2010 (Chu \& Davis 2011).

In terms of structural change, a new business lobby, the American Business Conference, was established in 1981 to represent the rapidly growing risk-oriented mid-sized finance and high-tech service sectors, gaining the ear of the Reagan administration and winning reductions in capital gains taxes and weakening of financial regulation. The ‘big three’ (NAM, Chamber and Roundtable) had with the addition of the ABC and the NFIB become the 'big five' Waterhouse (2014). Jeffrey Bimbaum (1997) compared the Roundtable to, 'a vacuum-tube operation struggling to survive in a digital age', its members 'too busy restructuring, reengineering, merging or acquiring to dabble in public policy’ (cited by Linder 2000, p. 210).

But while these structural changes are said to have undermined the position of the Roundtable as a cohesive central coordinating force, the Roundtable readily accommodated the structural changes to the economy, recruiting the CEOs of the major firms in the new industries. In 1988, the Roundtable leadership was drawn from these industries; Pfizer, Aetna, American Express and IBM, while major firms in rising industries such as IT (Microsoft, Yahoo) and retail (Walmart, Target) continued to join the Roundtable (Waterhouse 2014). Director interlocks may be an important force for corporate cohesion, though the evidence is mixed and there may be other mechanisms (Mizruchi 1996).

\subsection{Victim of success thesis}

Judis (2000) argues that the success of the business offensive against state regulation has been its undoing as the excessive short-term self-interest has stymied the political and institutional balance of interests necessary for the pursuit of a common good that provides long-term benefits for business. He argues that 
underpinning the great periods of US economic and social progress, the Progressive Era, the New Deal and the 1960s, were political-institutional combinations of strong public-spirited contest among political parties, an independent public service responsive to the balance among contesting interest groups and a non-partisan moderate policy elite organizations with vision of the common good. But by the 1990s political contest had become extremely partisan and deadlocked, the public service politicized, business investments in lobbyists outweighed the capacity of countervailing interests, and there was no willingness in elite circles to attempt to forge a non-partisan vision in the face of partisan hostility.

Mizruchi (2013) draws on this view, arguing that the victories of the conservative business elite consolidated by Reagan in the early 1980s removed the principal constraints on business - labour and government regulation - but in so doing removed the drivers of business unity. Banks, which through a central role in the interlocking director network through the post-war era, had turned their attention to financial services and investment and no longer mediated sectional conflicts within the corporate elite. Mizruchi offers two cases to support his view that class-wide elite cohesion has been broken, one concerning fiscal policy and the other healthcare. In the case of fiscal policy, he argues that the 1986 tax defeat led the Roundtable to retreat and then abandon efforts to resist Republican Tax cuts thereafter. With this abdication, no moderate public service oriented policy elite organisation remained to provide elite cohesion, as the National Civic Federation and the Council for Economic Development (CED) had in the past. Likewise, with healthcare, self-interested divisions within business delayed and threatened to destroy a healthcare reform package that would have reduced the costs of all participants, including business.

Judis’ (2000) analysis of despair for a lost liberal democratic equilibrium amounts to a moral exhortation, a call for a courageous educated elite to put aside short-term self-interest in favour of the long-term common good and to redesign institutions to better resist partisan capture. Yet the rise and decline of the great epochs of US progress can as readily, and more convincingly, be interpreted within a Gramscian 
framework. From this perspective, the Roundtable is engaged in an ongoing war of position, building coalitions and advancing and retreating tactically as necessary to maintain its hegemony.

The case studies illustrate the Roundtable acting constantly as a hegemon with mixed tactical success. Very successful in the 1970s, challenges in the 1980s but very successful in arguably the most important arena - international trade and investment. Mizruchi’s (2013) tax case needs to be interpreted in the larger context of the expanding trade and investment context. The tax deductions defeat of 1996 was followed by tactical success in reducing the deficit via marginal tax rises and spending cuts under Bush I and Clinton. The acceptance of a deficit and support for tax reductions with Bush II was not an abdication of principle but an act of pragmatic, tactical advance. Likewise, in healthcare, the Roundtable attempted to find legislative outcomes that would meet the needs of most of the varying business interests, and ultimately succeeded with its support for Obama care; this is characteristic of a hegemon, accommodating varying interests, not an expression of narrow self-interest.

\subsection{Hegemonic position}

The activity of the Roundtable as a hegemon, building tactical coalitions framed in terms of broad popular interest, is likely to see it centrally connected to other organisations in the policy environment. Building on some historical evidence discussed above, this section provides a systematic analysis of this proposition, employing a social network analysis of US lobbying activity.

Network analysis has previously identified the central position of the Roundtable among business organisations. In an informal analysis of the executive committees of ten business-planning groups, Burch (1983) found the Business Council to be the most central of these organisations, alongside the Roundtable, CED, Council of Foreign Relations and the Trilateral Commission. Burris (1992) in a more systematic and formal network analysis found the Roundtable, in particular, together with the Business Council, Conference Board and the Council of Foreign Relations as the most central organisations. More recently, Strangfeld (2006) found Roundtable member firms became more central in the interlocking director network among energy firms in the 1970s and 1980s. 
The analysis in this chapter makes use of quarterly returns made by registered lobbyists in accordance with the 1995 Lobbying Disclosure Act (Office of the Clerk of the US House of Representatives 2016). Where traditional social network analyses of director interlocks simply infers corporate cohesion (Cronin 2011), this approach offers direct evidence of the joint representational activity of business organisations. The data for this analysis comprise the quarterly returns of all registered lobbyists, detailing their representations to government entities during the period, for 68 quarters from the start of electronic archiving in 1999 and the end of 2015, 2 million observations.

The data from each quarterly register were modelled as an advocacy network, comprising directional ties from registered lobbyists to government entities; multiple representations of a lobbyist to the same government entity during the quarter were modelled as multiple ties. An example of an advocacy network, from the third quarter in 1999, is presented in Figure 6.2. The network was visualised using a spring-embedded algorithm with default settings from a Gower scaling in Netdraw 2.154 (Borgatti 2002). The circles are registered lobbyists, node size reflecting the number of representations registered in the quarter (their outdegree). The squares are the government entities being lobbied, their size reflecting the number of representations made to them during the quarter (their indegree). The arrows from one node to another indicate representations from lobbyist to government entity registered during the quarter. Nodes located towards the centre of the visualisation are more central to the lobbying activity.

\section{ENTER FIGURE 6.2 AROUND HERE}

Lobbying activity in this example is centred on the Senate and House of Representatives from a large mass of lobbyists. On the right is an array of the major economic departments, Treasury, Transport, Environmental Protection and Defense. Between these two poles of government lies a set of highly active lobbyists. These include peak trade associations, such as the Chamber and NAM; specialist lobbying firms; large individual corporations, such as IBM and GE, and the Roundtable. 
The social network analytics underpinning this visualisation provide some precision in the identification of influential positions in the network, beyond a simple count of the number of representations (indegree or outdegree centrality). For example a node's degree centrality can be weighted by the degree of the nodes it is connected to, to highlight nodes that are connected to more highly connected nodes (a metric known as eigenvector centrality). Closeness centrality highlights those nodes that have the shortest paths to all other nodes in the network. Betweenness centrality highlights nodes that are commonly on the shortest paths to each pair of nodes in the network, a measure of brokerage (see Cronin 2016 and Borgatti, Everett \& Johnson 2013 for accessible elaborations).

To evaluate the position of the Roundtable in the network of organisations in the policy environment, these common measures of network centrality were calculated for each registered lobbyist, each quarter. But these measures only make sense when nodes of the same type are considered. Two different types of organisations are evident in a combined network in Figure 6.2 - lobbyists and government entities, that is, a two-mode network. The act of lobbying is of a different quality to the act of being lobbied and while the data documents common behaviour among lobbyists, there is only partial information on the behaviour of those being lobbied, particularly their own interactions. So, in order to carry out the centrality analysis the network of lobbying activity alone needs to be extracted. The one-mode network of lobbyists can be extracted from the two-mode data by projecting a relationship between two lobbyists where they lobby the same government entity. So, where the Roundtable and the Business Council lobby Senate in the same quarter, a tie between the Roundtable and Business Council is projected. The subsequent centrality analysis then effectively models the relative competitiveness of each lobbyist in the lobbying activity.

The longitudinal dataset allows the measurement of the evolution of the competitiveness of lobbyists over time. To consider the position of the Roundtable within the policy environment during this period, the various dimensions of centrality were compared to the mean centrality of all lobbyists over time. A linear regression with an interactive variable was then undertaken to determine whether the trend in the 
Roundtable's position diverged from the mean trend during the period. In the regression equation (1), divergence is given by the magnitude and significance of the coefficient $\beta_{2}$.

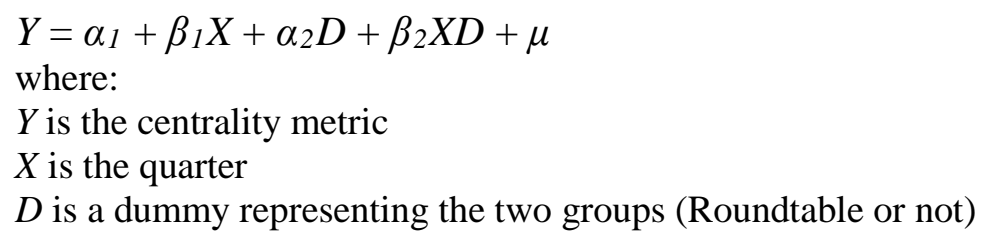

Metrics were calculated with the igraph package in R. Degree and betweenness centrality were normalised by adjusting for the total nodes in each network. Eigenvector and closeness centrality were normalised on a 0-1 scale. Betweenness was estimated betweenness with a cut-off of 6 steps. 126 observations and 2 degrees of freedom in each regression.

As shown in Table 6.2, all regression models fitted and accounted for much of the variation in the data. Roundtable centrality significantly diverged from the mean trend in the case of eigenvector centrality and converged towards the mean from a below-mean position in the case of betweenness centrality. There was no significant divergence from the mean trend for outdegree centrality or closeness centrality, while the intermediating role of the Roundtable in terms of all actors increased. This demonstrates that while the Roundtable did not increase the number of representations to government more than the mean during the period (outdegree), it was increasingly making representations in a manner similar to the most connected lobbyists (eigenvector centrality), that is, it was becoming more central among the most central lobbyists and becoming more of an intermediary.

ENTER TABLE 6.2 ABOUT HERE 


\section{Conclusion}

This review of the major business policy battlegrounds of the last fifty years indicates that reports of the decline of the Roundtable are greatly exaggerated. The organisation remains a powerful think tank with an effective modus operandi. The lean central organisation and direct engagement of the CEOs of the major US industrial corporations in its policy and implementation sees its strategy and tactics being honed by those at the forefront of capitalist competition and cooperation. These CEOs are highly focused on making a difference - identifying scope for value added and pursuing it vigorously. The heightened strategic and tactical sense translates readily into the policy arena, eschewing partisan ideology for pragmatic, tactically astute, legislative lobbying, with clear ability to build coalitions and to frame the specific goals within broad, popular themes in the polity.

While critics may yearn for a policy environment that is more accommodating of the broad range of social actors, such as labour and government, this does not mean the US polity is lacking hegemonic players. The Roundtable has proved itself to be a hegemon in the Gramscian sense, achieving specific goals by building effective coalitions. For a hegemon, tactical gains and losses occur within a longer-term war of position.

The persistence of the Roundtable and its effective modus operandi indicates that the forces of elite cohesion are wider than those formed by the interlocking personnel between organisations. It has been able to accommodate new powerful organisational entities that have emerged with changes to the structure of the economy and continues to become increasingly central to the US policy advocacy network. 


\section{References}

Bimbaum, Jeffrey (1997). “Washington’s Power 25: Which pressure groups are best at manipulating the laws we live by?” Fortune, 8 December, 136(11), 144-58.

Borgatti, S.P. (2002). Netdraw network visualization. Harvard, MA: Analytic Technologies.

Borgatti, S.P., Everett, M.G. and Johnson, J.C. (2013). Analyzing social networks. London: Sage.

Burch Jr., P. H. (1983). The American establishment: Its historical development and major economic components. In P. Zarembka (Ed.), Research in Political Economy (Vol. 6, pp. 83-156). Greenwich, CT: JAI Press.

Burris, Val (1992). Elite policy-planning networks in the United States. Research in Politics and Society, 4, 111-134.

Center for Responsive Politics (2016). Lobbying database. http://www.opensecrets.org/lobby/

Chu, J. S. G., \& Davis, G. F. (2011). Who killed the inner circle? The collapse of the American corporate interlock network. SSRN Electronic Journal. http://dx.doi.org/10.2139/ssrn.2061113

Coase, Ronald H. (1959). The Federal Communications Commission. Journal of Law and Economics, 2, $1-40$.

Cronin, Bruce (2011). Networks of corporate power revisited. Procedia - Social and Behavioral Sciences, $10,43-51$.

Cronin, Bruce (2016). Social network analysis. In Frederic S. Lee and Bruce Cronin (eds) Handbook of research methods and applications in heterodox economics (pp. 237-252). Cheltenham, UK and Northampton, MA: Edward Elgar.

Derthick, Matha \& Quirk, Paul J. (1985). The politics of deregulation. Washington, DC: The Brookings Institution.

Domhoff, G. William (1983). Who rules America now? Englewood Cliffs, NJ: Prentice Hall.

Domhoff, G. William (2006). Who rules America: Power, politics and social change, $5^{\text {th }}$ Edn. New York: McGraw-Hill.

Ehrbar, A. F. (1982). The battle over taxes. Fortune, April 19, 58-63.

Gramsci, A. (1971). The intellectuals. Selections from the prison notebooks, ed. Transl. Q. Hoare and G. N. Smith (pp. 3-23). London and New York: Lawrence \& Wishart and International Publishers.

Judis, John B. (1995). Abandoned surgery: Business and the failure of health reform. American Prospect, (Spring). Retrieved from http://prospect.org/article/abandoned-surgery-business-and-failure-healthreform

Judis, John B. (2000). The Paradox of American democracy: Elites, special interests, and the betrayal of public trust. New York and London: Routledge. 
Kolko, Gabriel (1963). The triumph of conservatism: A re-interpretation of American history, 1900-1916. New York: Free Press.

Lee, Frederic S. \& Cronin, Bruce (2016). Introduction. In Frederic S. Lee and Bruce Cronin (eds) Handbook of research methods and applications in heterodox economics (pp. 1-12). Cheltenham, UK and Northampton, MA: Edward Elgar.

Linder, Marc (2000). Wars of attrition: Vietnam, the Business Roundtable, and the decline of construction unions. Iowa City, IO: Fanpihua Press.

Martin, Cathie J. (1991). Shifting the burden: The struggle over growth and corporate taxation. Chicago: University of Chicago Press.

Milner, H. (1988). Resisting protectionism: Global industries and the politics of international trade. Princeton, NJ: Princeton University Press.

Mizruchi, Mark S. (1996). What do interlocks do? Analysis, critique, and assessment of research on interlocking directorates. Annual Review of Sociology, 22, 271-298.

Mizruchi, Mark S. (2013). The fracturing of the American corporate elite. Cambridge, MA: Harvard University Press.

Office of the Clerk of the US House of Representatives (2016). Lobbying Disclosure Act guidance. http://lobbyingdisclosure.house.gov/amended_lda_guide.html

Slavin, Peter (1975). The Business Roundtable: New lobbying arm of big business. Business \& Society Review, 16, 28-32.

Strangfeld, J. A. (2006). Cohesion in the formation of the 1979 national energy policy. University of Oregon.

Waterhouse, Benjamin C. (2014). Lobbying America: The politics of business from Nixon to NAFTA. Princeton and Oxford: Princeton University Press. 
Figure 6.1. Business Roundtable - Registered annual expenditure on lobbying 1998-2015

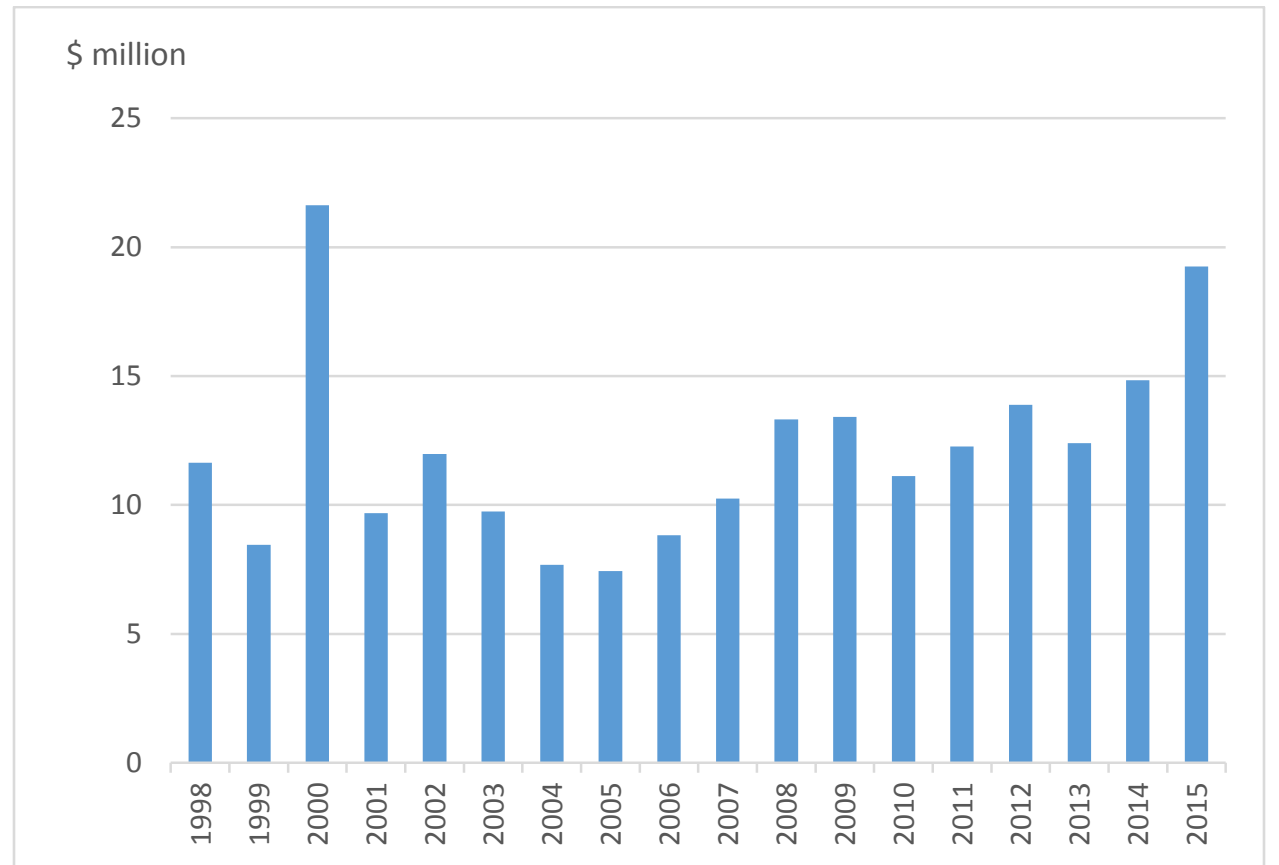

Source: Center for Responsive Politics (2016) 
Figure 6.2. Advocacy Network Q3 1999

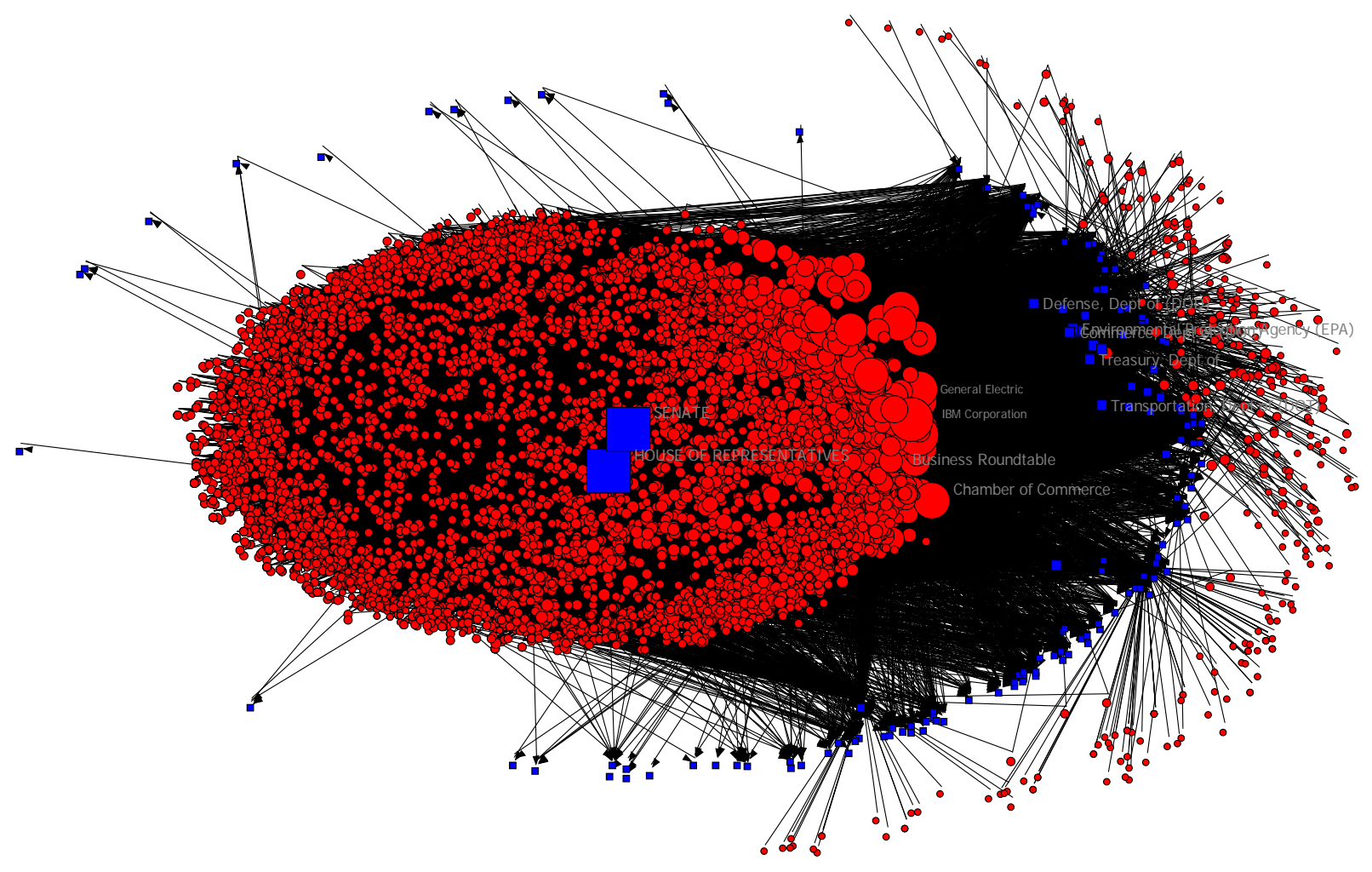


Table 6.1. Outcomes of Roundtable policy advocacy

\begin{tabular}{ll} 
Policy Area & Outcome \\
\hline Labour rights & Stalled, reframed; won extra-legislatively \\
Inflation & Reframed, won \\
Consumer protection & Reframed, stalled \\
Regulation & Reframed, stalled \\
Fiscal policy & Reframed, initially won, lost, sidelined \\
Free trade and investment & Reframed, won \\
Health care reform & Stalled, compromised \\
\hline
\end{tabular}


Table 6.2. Business Roundtable relative centrality 1999-2015

\begin{tabular}{|c|c|c|c|c|c|}
\hline Centrality metric & Mean & Roundtable & Divergence & $\left(B_{2}\right)$ & Adj $R^{2}$ \\
\hline Outdegree & 0.916118 & 0.956491 & .0002652 & & 0.1231 \\
\hline Eigenvector & 0.03313 & 0.080531 & .0008937 & $* *$ & 0.3766 \\
\hline Closeness & 0.361674 & 0.319951 & -.0000521 & & 0.3971 \\
\hline Betweenness & 0.0008093 & 0.0000915 & .0000428 & $* *$ & 0.2002 \\
\hline
\end{tabular}

